\title{
EU-FINANCED PERIPHERAL LARGE-SCALE INFRASTRUCTURE PROJECTS AND THE WHITE ELEPHANT SYNDROME: THE EXAMPLE OF RAIL BALTICA
}

\author{
Viljar VEEBEL - Raul MARKUS - Illimar PLOOM
}

(Received: 4 July 2017; revision received: 19 October 2017; accepted: 21 January 2018)

\begin{abstract}
The present study revolves around the question of the appropriateness of "the White Elephant syndrome" to characterise the nature of the planned trans-Baltic railway project Rail Baltica (RB) in terms of its initial financing, long-term profitability and symbolic importance. Whereas, in general, the expected outcome of the project goes well together with the EU Cohesion Policy goals, in its concrete application RB could serve as an example of the tendency of politicians and public servants to institutionally lock themselves into certain irrational choices about publicly financed megaprojects. This is what "the White Elephant syndrome" metaphor illustrates. Methodologically, this paper aims to analyse whether RB meets the common criteria of "the White Elephant syndrome" of public investments or if it can be seen as a sustainable and profitable long-term project after the initial investment.
\end{abstract}

Keywords: "White Elephant syndrome", European Union, structural funds, public policy

JEL classification indices: E61, O21, R13, R41, R42

Viljar Veebel, corresponding author, Associate Professor, Chair of Political Science and Strategic Studies, Baltic Defence College, Tartu, Estonia. E-mail: viljar.veebel@gmail.com

Raul Markus, Researcher, Department of Logistics, Tallinn University of Technology, Tallinn, Estonia. E-mail: Raul@optium.ee

Illimar Ploom, Associate Professor, Department of Economy, Ragnar Nurkse School of Innovation and Governance, Tallinn University of Technology, Tallinn, and University of Tartu, Center for EU-Russia Studies, Estonia. E-mail: illimar.ploom@gmail.com 


\section{INTRODUCTION}

The process of political decision-making about carrying out projects with large socio-economic impacts to society should be based on realistic measurable visions and calculations of the costs and potential direct and indirect benefits or losses of the project. At the European Union (EU) level, the coordinated implementation of infrastructure projects in the framework of the Trans-European Transport Network is expected to contribute to the effectiveness of the overall EU transport system and to enhance economic growth, competitiveness and employment in Europe. At the same time, the past experience with high-speed railways in the EU enables to point to the tendency of both the overestimation of project revenues and the underestimation of costs related to the establishment and maintenance of high-speed railway tracks, and generally to the non-responsiveness of the project to the actual needs. One of the latest big scale projects in the sphere of transportation is the attempt to connect the three Baltic States better to the European railway network. So far, railways have not been a priority for these small states. Rail services between the Baltic States, let alone with the rest of Europe, have been nearly non-existent.

In this light, the paper focuses on the question of whether contrary to the expectations the Rail Baltica (RB) project as a part of the EU North Sea-Baltic corridor could turn into an infrastructural "White Elephant" ${ }^{1}$ and become a burden to the Baltic countries. Thus, the primary focus of the paper will not touch the immediate cost-benefit analysis of the project, but rather the question of how realistic are the hopes that this project of solidarity will actually be economically and socially viable. If the project is over-dimensioned, will there be a possibility for a down-scale? If not, then RB will not be economically viable (including enhanced security) and remarkable public investments can be wasted and constant subsidies will be required. From a practical perspective it is also important who will bear these costs, the Member States (MSs) or the EU, and what the role of the EU subsidies is? How could one make sure that they will be socially useful in a true sense and not give a push for over-dimensioned projects? In its turn, drawing especially on the contradictory findings and assumptions of the publicly commissioned studies, this paper could but will not put forward an alternative calculation. Instead, it concentrates on the procedural and institutional traps and problems that characterize the planning and implementation phases of the RB project.

1 In the current study "the white elephant" metaphor refers to a large infrastructural investment (often in the form of partial gift from central authority) whose cost of maintenance is not in line with its value. It is often approved for political or symbolic reasons and it cannot be sold in normal circumstances (Girginov 2010; Papanikolaou 2013; Prasser 2007). 
From the theoretical perspective, the article discusses two apparently competing but inherently complementary perspectives. The first one focuses on whether it is justified for the EU (and for the governments of the MSs) to intervene into market based solutions. An allocation of resources in a significantly deviating manner from the efficient market solution is contrary to the primary aim of the European single market and its competition policy. Large infrastructure projects like the RB, while appropriate and beneficial in the core countries tend to become unsuccessful in the EU peripheral states. Even indirect effects and benefits might not save such projects. The second perspective relies on the broad justification of any regional policy. In a typical nation or even more so in a regional supranational union like the EU, the question of uneven development of sub-regions or peripheries is a crucial aspect that needs an elaborated conceptualization and also an adequate response in terms of regional policy measures. Good infrastructure together with good quality public services is a sort of equalizer of the game, putting (ideally) everybody regardless of the geographic and other regional factors on an identical starting point. The question nevertheless remains if such investments will be sufficiently weighed and adequately bolstered by calculations.

The present study will revolve around the question of the appropriateness of the metaphor of "the White Elephant" to characterize the nature of RB in terms of its initial financing, long term profitability and symbolic importance. Methodologically, this study aims to analyse whether RB meets the common criteria of "the White Elephant syndrome" of public investments or if it should be seen as a sustainable and profitable long term project. As stated earlier, the sustainability and profitability of the project will look for a balance where the EU investments need to achieve an effect where the profits generated by the project will surpass domestic subsidies by a Member State.

The analysis will be conducted on two levels; first by assessing the expected outcomes of RB against the criteria of "the White Elephant syndrome" and secondly evaluating its expected business performance on a four-level scale in terms of the project's survivability with and without donations. More precisely, it is assessed which of the following four categories applies to the RB project best:

a) It is a profit-oriented project which is sustainable to generate profit when the initial investment is included in the price of the service;

b) It is a partially profitable project which is sustainable when the maintenance costs are included in the service price, but the initial investment needs to be excluded;

c) It is a project which is not directly profitable in terms of covering the initial investments and the maintenance costs, but the benefit for society is expected to come from the internalization effect by additional tourism, investments, etc.; and can be measured in terms of indirect financial benefits; 
d) It is a project which is profitable merely for the contractors and for the state budget of the target countries in its construction stage, but is not profitable in any previously described combination in terms of direct or indirect financial income; thus, it needs not only additional financing through-out its lifecycle but also the coverage of the indirect losses; its main importance and necessity will be explained in terms of security needs, environmental gains and symbolic importance as an element in the European integration.

As its final outcome, this article will offer conclusions in terms of how many initial components of "the White Elephant syndrome" are fulfilled based on the assessments conducted by Ernst \& Young, Estonian State Control, and AECOM.

\section{THEORETICAL DILEMMAS IN ASSOCIATION WITH LARGE-SCALE INFRASTRUCTURE PROJECTS}

This section outlines theoretical perspectives that are not only abstract alternatives but to some extent represent the inner dilemmas, if not outright conflict, of the EU policies. It first deals with the 'market failure' correction, known also as the neoliberal perspective; with the 'government failure' correction or the institutional perspective; with cost-benefit dilemmas related to centre-periphery preferences and the impact of the European dimension to the assessments; and finally with the White Elephant syndrome.

\subsection{Neoliberal perspective in evaluating public infrastructure projects}

The classical liberal economic theory considers competition as a pre-condition for the operation of market forces. Goods and services are subjected to competition and their price is determined by market demand and supply. Accordingly, markets are expected to emerge spontaneously and be self-regulating, pricing mechanisms should reflect fairly the value of goods and services, and state interventions in the economy are undesirable (Thorsen 2009: 3).

The current decade has seen the ideology of neoliberalism having significantly declined in importance due to the setbacks of the recent economic and financial crises. Among other things, these setbacks clearly teach that due to market failures some goods or services may prove unprofitable for a private company, but may still provide larger socio-economic benefits or other general gains to society. Their benefits would be clear while their offering on a commercial basis is not feasible. The theoretical concept that captures this situation is known under the name of non-internalisable benefits. Some services like infrastructure, 
while not immediately profitable in the market, are still necessary for ensuring a wider and stronger basis for growth, and can be economically beneficial on a wider societal scale. Yet, the very same phenomenon is also a problem that makes large infrastructure projects a delicate topic and needs careful consideration. A project, which cannot be viable through an ordinary market mechanism of selling a service to clearly definable customers, necessitates a much more complex analysis of wider beneficiaries that are remote and whose benefits may defy easy calculation.

The role of non-internalised benefits of transport connections can be illustrated by the example of aviation. An airline can contribute to the local employment and increase tax revenues, bring tourists who boost country's exports, give access to businessmen to make direct investments to the national economy, contribute to wider cultural relations and make countries and regions prosper. Thus, airline connections can be profitable for a country or a region; however, the profits in the form of revenues may not be immediately available for aviation companies to internalise (Crocioni - Newton 2007: 152). Further, drawing on the studies focusing on previous infrastructural projects, the internalization effect for a region and society is not guaranteed as such (Prassner 2007: 50). In certain cases, existence of infrastructure may not have a positive socially internalizing effect for industrial development: if there are no transit flows or local industrial potential, additional railway will not make them appear.

There is also a second complication with projects where social benefits tend to dominate the cost-efficiency calculation: with more critical projects, while appearing to be in balance in the planning stage, these projects may actually need systematic subsidies to cover the deficit between actual revenues and operational costs. Or these subsidies may go against state aid rules of the EU. The Baltic States have already experienced severe problems with national airlines providing vital social services but needing growing subsidies for everyday functioning that cannot be easily accommodated within the EU state aid framework (Veebel et al. 2015).

\subsection{The institutional perspective}

If the above section presents the neoliberal model and its critique, the present section turns the tables and views the cases where government investments can be considered as failures. Thus, next to market failures, also the possibilities of government or administrative failures exist. The theory of government failures focuses on the rational public policy processes and argues that a government failure may arise when government has created inefficiencies because there was 
no need for the intervention or the intervention was not efficient enough to generate greater net benefits (Vining - Weimer 1990; Dollery - Worthington 1996; Winston 2006; etc.). As argued by Winston (2006), the empirical results suggest that welfare costs of a government failure may be considerably higher than that of a market failure.

Government failure is caused by the following factors: a) self-correcting nature of certain market failures which makes government intervention unnecessary; $b$ ) short-sightedness, inflexibility and conflicting policies of government agencies; and c) political forces that allow well-defined interest groups to influence elected and unelected officials to initiate and maintain inefficient policies that enable the interest groups to accrue economic rents (Winston 2006: 4).

Government failures can also be explained by neo-institutional theories which argue that rules and norms tend to dominate over actual goals and broader gains, and that decision-making is dominated by institutional habits, procedures, norms and compromises that prefer expectable, rational, continuing, regulated and less risky choices. To this effect, the institutional approach partially overlaps with the concept of path dependence, which relies on a statement that "history and experience matters". In particular, path dependence describes a situation where the probability of a subsequent event is linked to the earlier actions of stakeholders. Ackermann explains path dependence as a cyclical process where current alternatives are limited or affected by past decisions (Ackermann 2001: 22). This approach relies on the argument that it is difficult to withdraw or to "step aside from the well-known road" due to the scale effects, positive externalities or other factors (Döring - Rose 2002: 11). This could lead to a "lock-in" situation: the entry of a system into a trapping region which it cannot escape without the intervention of some external force or shock. To quote David (2000:3) "path dependent systems may thus become locked in to attractors that are optimal, or that are just as good as any others in the feasible set, or that take paths leading to places everyone would wish to have been able to avoid, once they have arrived there". Flyvberg (2007: 578) has stressed that government failure can be also the result of high level of misinformation that decision makers face when taking decisions whether to build or not, and which are the risks combined with optimism bias, and also strategic mispresentation to compensate lack of information and skills. Political-economic explanations see planners and promoters as deliberately and strategically overestimating benefits and underestimating costs when forecasting the outcomes of projects. They do this in order to increase the likelihood that it is their projects, and not those of the competition, that gain approval and funding (Flyvbjerg 2007: 583). 


\subsection{Centre - periphery debate}

Building partly on the argument of non-internalisable social benefits, this section wishes to introduce yet a further vital dimension to the discourse, a centreperiphery debate. The synergies of modern developed economies have amplified the growth potential and immersion potential of the greater cities and especially megapolises to such an extent that the drive from smaller towns and less densely populated areas has been widely and severely felt. This has been a long trend (Myrdal 1957). The growing inequalities have been an effect of such developments (Massey 1979), even within a modern urban environment. From an immediate market economy's perspective, a tightly populated city is in every sense more efficient than the same population scattered in a larger territory. However, since the historical settlement patterns have followed the rural production logic of more or less evenly divided regions and towns, the effect of connecting people has been largely achieved by improving infrastructure and services like roads and public or private transport or airways and airlines. Thus, whereas among the regional policy measures, there are needs for economic, social and other tools, the role of infrastructure in regional development cannot be overestimated (Stephan 2001).

Now, in a country where the balance between regions and cities is not secured, i.e. where the drive to the bigger centres is heavy, the otherwise logical market-driven process may incur severe costs. To avoid these imbalances and unnecessary costs, the governments design and implement regional policies that balance the drive towards centres. This can be done in several ways, through tax exemptions, special investments, subsidies, etc. One way to overcome the peripheral status of a region is to help connect it with the neighbouring regions, cities and the centre. The RB project can be viewed as such an attempt. Indeed, what makes this kind of investments even more needed is the specific EU context, where the question is not about the semi-autonomous regions but often about all the member states. This realization has been behind the EU policies, historically targeting more intra-state imbalances by establishing mechanisms such as the European Regional Development Fund (ERDF) (Nijkamp 1986) or the inter-state imbalances through mechanisms like Trans-European Transport Network (TEN) financed through ERDF, Cohesion Policy Fund and other sources (European Commission 2017b).

Therefore, next to the viewpoint seeing the EU as a single market, the actual situation needs to consider the fact that the member states are still sovereign partners who wish to retain and advance their competitiveness in the EU. Against this backdrop, the focus is shifted to the question of whether the European integration should be considered as the 'highest value' per se for what the interests of 
small peripheral countries might potentially be sacrificed, or the aim of integration should be to improve the realization of national interests in the framework of the common policies. Supranational 'value' at the EU level might be related to the maintenance of a competitive environment, which is unambiguous to all the economic agents and which does not allow exceptions. Thus, even if the liberal market conditions and fair competition might have positive corrective impact at the EU level, they may also lead to negative consequences at the local level (i.e. restricted access to services or sharp rise in unemployment in a particular member state). For this reason, it is important to find a right balance between the interests of the EU as a whole and the interests of the member states in making the European integration process a success. Seen in the above perspective, the investments into the peripheral regions and member states are of utmost importance, also for the viability of an EU project. This is also why the actual usefulness of the large scale infrastructure projects to the specific regions and the member states needs to be carefully analysed and discussed. And, it is precisely because of these reasons that while a natural position is to welcome the wish to invest into less well-off regions, there must be given extra care for not turning these investments into the White Elephants.

\subsection{The White Elephant syndrome}

The White Elephant syndrome is one of the institutional effects that appear when political motivations over-rule the economic ones. A White Elephant is a metaphor for an investment or partial gift whose cost of upkeep is not in line with the usefulness or value of the item. From a business perspective, the White Elephant refers to an unprofitable investment, property or business that is so expensive to operate and maintain that it is difficult to actually run it with a positive cash flow, make a profit or sell it with the initial price (Girginov 2010: 16 and Papanikolaou 2013: 6). To be more specific, these are cases where there is a clear discrepancy between the unrealistic and overly ambitious intentions involving the building of large prestige on the one hand, and an inability to subsequently manage and exploit them in a sustainable way on the other hand. These are acts of vanity, megalomania and ostentation inconsistent with the reality in small countries. This kind of behaviour could also be described by the term, neologism micromegalismus (Papanikolaou 2013: 6). Crucially, the projects that tend to become White Elephants require considerable post-completion maintenance and support and other lasting valuable resources that could be used elsewhere. Such projects, because of their status, size, and complexity too often disrupt effective project manage- 
ment practices in their original scoping, assessment and implementation, and fail to have clear purposes or functions (Prasser 2007). Related studies, such as the one carried out by Mangan - Dyreson (2010) and Flyvberg (2007) point out the scale of budget overrun and significant financial surcharges beyond the originally planned costs, as the reason to use the symbol of White Elephant. In most cases when the White Elephant syndrome appears, the project managers are not using pilot or test project options, arguing that previous tests are not possible, too expensive or that there is not enough time. Prassner (2007), Syvret - Syvret (1996), Papanikolaou (2013) and Scott (2007) describe the White Elephant Syndrome consisting of the following components:

1) It is a gift or a partial gift offered to a local authority, introduced as a symbol of integration and progress. The receiving side will receive the gift and bear only part of the costs. Following the delivery or completion, the White Elephant will be growingly resource consuming.

2) The White Elephant has no market value and cannot be sold under normal circumstances.

3) It does not consist of any modern, client-oriented or rational technology: it is huge, out-dated and non-adaptable for local needs.

4) Goals at the beginning, during and after project implementation remain unclear and are dominated by post-project justification.

5) It is often supply rather than demand-driven -"we can build it", rather than we need it, often expressed in the "build it and the clients will come syndrome".

6) Poor project governance with little separation between project management and project client is resulting in excessive interference in design, budgets, and management; limited initial or independent evaluation of the project's viability so that expectations are exaggerated, optimistic, or unspecified; it is unclear what level of certainty and trustworthiness the project plans and preliminary assessments have.

7) Timeframes are compressed, uncertain, or established to meet election cycles, with little accompanying consultation with relevant stakeholders taking place.

8) High level of misinformation that decision makers face, such as whether to build and what the risks are. The results are costs overruns and/or benefit shortfalls.

From a White Elephant project, the best option for the public is that it finally turns out to be able to cover its maintenance costs from its revenues without subsidies after the initial investment is done (Syvret - Syvret 1996). 


\section{RAIL BALTICA: CHRONOLOGY AND MAIN CHARACTERISTICS OF THE PROJECT}

Even if through their domestic or Baltic efforts the railway connections have stayed rather underdeveloped. Hence, connectivity between Eastern and Central Europe and especially with some prominent European capitals has been a longstanding priority in the Baltic political rhetoric.

The idea of a direct high-speed railway connection between the Baltic countries and the rest of Europe was for the first time officially envisaged in 1994. The political document was called "Vision and Strategies around the Baltic Sea 2010: Towards a Framework for Spatial Development in the BSR" and was adopted by the representatives of Belarus, Denmark, Estonia, Finland, Germany, Latvia, Lithuania, Norway, Poland, the Russian Federation and Sweden. Further steps on the road to integrate the Baltic countries with the European railway network were conducted in the early 2000s through the project of regional spatial planning and development (Rail Baltica: Project description 2016). In 2003, four countries Estonia, Latvia, Lithuania and Poland - agreed on the key aspects of conducting further studies for making investments in the RB project.

When the Baltic countries joined the EU in 2004, they defined the implementation of the RB project as the main regional challenge in the transport sector (Baltic Council of Ministers 2005: 2) and the project was included in the list of priority projects according to the proposal of the European Commission (Rail Baltica: Road of the future 2016). As regards Estonia, in 2005 the RB project was also included into the National Spatial Plan Estonia 2030+.

Potential difficulties in implementing the project at the regional level have already been highlighted in the report submitted by the Baltic Council of Ministers in 2005. The report revealed low north-south traffic flows, interoperability (the difference of gauge between the railway networks of the Baltic countries and those of Poland and Germany), and raised the question of competition with road and air transport.

In 2006, a joint declaration on the implementation of the RB project was signed between Estonia, Latvia, Lithuania, Poland and Finland, and in 2010 all five countries reinforced the previously shown interest at the governmental level. They signed a Memorandum of political will to continue with the project (Rail Baltic Final... 2011). More recently, another joint declaration was adopted by the Prime Ministers of Estonia, Latvia and Lithuania on 10 November, 2015. The declaration set the objective to create the new Trans-European railway route linking Helsinki, Tallinn, Riga, Kaunas, Warsaw and continuing to Berlin (The Rail Baltic Project 2015). 
The project took a major step forward in 2015 when the European Commission approved funding for three projects, prioritizing: 1) studies and works on different sites in Estonia, Latvia, and Lithuania, 2) development of the EU standard gauge railway line in Lithuania from the border with Poland to the Latvian border, 3) upgrade of the existing railway line in Poland, to the EU standard gauge line. The project was foreseen to be financed from the Connecting Europe Facility (CEF) and the costs of the three projects were estimated to be in total 734 million euro. In 2016, the European Commission approved funding for RB in the amount of 202 million euro from the CEF as a part of a second round of funding. In 2017, the project is in a planning phase: the initial cost-benefit analyses have been conducted; all three countries have agreed on the further procurement model and mutual responsibilities in implementation of the project and some technical distribution, such as VAT distribution for the project (The Baltic Course 2016). As in 2017, the planned features of the RB railway connection consist of:

a) A railway route with a total length of more than 750 kilometres.

b) The route will be completed not earlier than in 2025 and would be operational with full load in 2035.

c) The railway is double-track and uses the European standard gauge $1.435 \mathrm{~mm}$. Connection is planned for both passenger and freight transport. Trains are powered by electricity, making the transportation environmentally friendly.

d) Trains can travel at speeds of up to $240 \mathrm{~km} / \mathrm{h}$, but in most areas the speed will be only $160 \mathrm{~km} / \mathrm{h}$.

e) Total costs are estimated to be 5.8 billion euros from which 1.1 billion are expected to be paid by the linked member states (Klava 2017: 12). The planned initial investments are 1.9 billion euros form which the Estonian share will be 570 million euros, Latvian 650 million euros and Lithuanian 675 million euros.

In terms of market situation, the main competitors of RB are Nordica ${ }^{2}$ and airBaltic $^{3}$, respectively Estonian and Latvian national airlines, of which particularly the latter is expected to benefit the most since due to its relative size, the partly low-cost carrier pricing model and the large nomenclature of routes, the Riga airport will be made easily accessible to the Lithuanian and Estonian clients. The difference compared with the present situation will be clear - at the moment airBaltic needs to provide the costly feeding routes between Riga airport and Vil-

2 Nordica AS is an Estonian state owned national airline company, focusing mostly on destinations in the Baltic States and in Central and Eastern Europe, departing or arriving from Tallinn, Estonia.

airBaltic is a Latvian based regional airline company operating mostly in the Baltic area and between the Central and Eastern European destinations. 
nius, Kaunas and Tallinn. The two mentioned flag carriers are supported by the national governments and offering starting prices equal to the expected RB ticket prices. A further competitor is the coach company, Lux Express that operates with more than $50 \%$ lower prices than the ones foreseen in the RB business plan. In terms of Riga-Tallinn pricing, volumes and competition situation, the picture would look as follows (Ernst \& Young 2017): in year 2035 the amount of passengers from Tallinn to Riga is estimated to be 628,000 (in average is 700 passengers per day); Rail Baltica would offer a 2-hour trip for 38 euros while Lux Express is currently servicing a 4-hour trip for 17 euros and airBaltic asks 28-64 euros for an 1-hour trip. To be profitable, the volumes of cargo and passengers are expected to grow substantially. It seems that Ernst \& Young expects the cargo volumes to be supply based as no source of industrial or transit growth is explained, leaving an impression that the existence of railway is the main factor impeding larger industrial production and transit (Rail Baltica Global 2017: 11).

\section{IS RAIL BALTICA A PROFITABLE PROJECT OR ONE SUFFERING FROM THE WHITE ELEPHANT SYNDROME?}

Some open questions still remained: the cost-efficiency calculations are confused by the inability to define the exact amount of the initial investment by the national governments (e.g. in the case of Estonia the range has been between 270 million euros and 600 million euros). The summarised cash flow is expected to be -4.1 billion euros while the total socio-economic profit is expected to be 18 billion euros. This will pose a major long term challenge: while seen beneficial socially, $\mathrm{RB}$ will need subsidies for initial investment, and later for renewal and everyday maintenance.

\subsection{According to the available assessments, how well the RB meets the market economy criteria?}

Although good connectivity between Eastern and Central Europe, and in particular access to some prominent European capitals, has been a longstanding priority in the Baltic political rhetoric, the local efforts to improve and develop the existing railway connections have stayed rather underpowered, indicating both the lack of profitability and governmental readiness for guaranteeing long-term subsidies. In addition, so far the railway network in the Baltics has mostly been serving freight transport, especially of Russian origin and, only recently, there 
has been a noticeable rise in the passenger transport services (with the help of the state subsidies).

Although the RB project has its roots in the early 1990s, the first comprehensive cost-benefit analysis of the project was conducted only in 2011. The report was conducted by the AECOM Limited (Rail Baltic Final Report 2011). In the report, under certain assumptions the financial analysis of the project estimated a positive cumulative cash flow in all years and, therefore, the project was assessed as financially stable. However, the financial indicators of the investment showed negative results without the EU funding. As a conclusion, the report stated that "there should be no need for subsidies during the operational period, although in order to help stimulate initial demand, in particular for freight traffic subsidies may be helpful during the start-up period". It also indicated that on a country level, best results are expected for Estonia, as passenger benefits are accrued by having three stations (Tallinn Central, Tallinn Airport and Pärnu) in comparison to a single station in Latvia and two in Lithuania (by now, the situation is changed as far as a special line to Riga Airport is also included in the project). In addition, the freight demand was estimated to be high as a result of the large flows from Russia and Finland. The construction costs were estimated to be relatively lower also in the case of Estonia. However, the political aspect was seen in the report as "a serious factor in the future of this project both in terms of the desire of the EU to link the Baltic countries with the rest of the EU using a standard gauge railway and in terms of the individual Baltic countries whose development could be stimulated by this project" (Rail Baltic Final Report 2011). The report published in 2014 by the Directorate-General for Internal Policies (European Parliament) highlights the export/import figures as a cause of concern and discusses different scenarios that could not be positive for all the countries involved in the project. The study suggests that trains may be relatively full from east to west (from Russia to Germany or to the Baltic countries) or north to south, but not on their return journeys, which does not make it cost-effective (Directorate-General... 2014: 42).

At the national level, local experts in Estonia also argued that the AECOM analysis was based on unreasonable assumptions and unrealistic expectations as regards the volume of the passengers and goods transport (Neivelt 2014; Tammistu 2016 ), questioning the reasonability behind the selection of the particular route of the railway connection (Humal 2016) and stressing that today the results of the survey are definitely out-of-date (Lend 2016). Likewise, local experts have stressed that the sources for covering the annual operating costs and capital costs of RB are unclear and also that the already existing railway network in the Baltic countries should be maintained next to the construction of the RB high-speed railway (Koppel 2017: 50). 
A more recent analysis of the costs and benefits of the project has been published in April 2017. In contrast to the earlier AECOM report, the new report by Ernst \& Young, while more realistic on the revenue side, is simultaneously more optimistic, and the optimism is mostly based on the economic developments in Finland. The final report published on 24 April, 2017 indicates that the market analysis and forecast modelling shows a clear potential for the RB project both in terms of the passenger and freight flows and the potential is sufficiently balanced. However, without public co-financing the RB project is not financially viable and its discounted net revenues do not cover discounted investment costs over the lifecycle of the project, partially attributable to the infrastructure charging principles stipulated by the EU transport policy. Following the initial investment, the infrastructure manager has foreseen to reach a breakeven point in the year 2031 and could be financially sustainable from this point onwards, the annual revenues from railway undertakings exceeding the annual operating costs (Rail Baltica Global... 2017). The report also stresses that due to the uncertainty in regard to the EU Cohesion and the CEF policy after 2020, the project co-financing aspects have been presented as sensitivity scenarios. As one of the authors of the study, Nauris Klava stresses, the main change from the AECOM study is that "connecting with Europe" ceases to be the aim at least for the Estonians and Latvians. The analysis also indicates that the construction stage is seen as economically profitable, while the operational stage is seen only socially profitable, while financially complicated (Klava 2017: 12).

However, both of the economic reports conducted in 2011 and 2017 appear to suffer from the overestimation of project revenues. A railway connection already exists between the three Baltic countries and their capitals but it has not found much use. This poses a question of where the extra passengers and freight would come from to make the planned scale of the project reasonable? As to the freight transport, at least in the Baltic Sea dimension, there exist good ports and seaways. Admittedly, the high-speed aspect of the project has foremost been related to passengers. Thus, the original purpose of the RB project has been seen in a further extended connection for the passengers with Central Europe, particularly with Germany. Nevertheless, for passengers, modern flight connections are more economical time-wise and often also in terms of service prices.

When combined with the expected internalization effect, the assessments often assume that the added value of the RB should and could not be measured in money, but in terms of its wider impact to the local economy. Nevertheless, the Baltic States already have national airlines with the same aim in terms of passenger transport and there also exists a functional railway from Tallinn to Vilnius. The advantages over existing solutions are presented, but in a relatively simplified way: e.g. all passenger costs are calculated from capitals, while in practice 
many passengers need to travel first about 200-300 kilometres before reaching the closest RB station. The calculations can likewise be questioned as e.g. the comparative prices of airline tickets seem to be selected from the most expensive options and, once again, the price comparisons are made only with trips beginning from RB stations, and not considering that more than $50 \%$ of the Baltic population does not live in the RB station cities and due to underdeveloped public transport networks might have difficulties in reaching these stations.

In terms of cargo, it is also expected that all of the existing railway cargo moves from the old Russian-standard railway to the new European standard railway. A crucial issue is that within the RB cost/revenue assessments the maintenance and other costs of the state-owned infrastructure and public transport companies (like national airlines) should also be counted. It is vital as far as these companies and services cannot survive without state donations, and the subsidies have also been justified as contributing to the life-line connections to Europe and providing large non-internalizable benefits. So, basically by financing the RB, the Baltic States will necessarily hit the market of their own national airlines (as well $\mathrm{LOT}^{4}$ ). There is a belief that a general optimism will boost the use of RB for cargo, but it is hard to concretize which cargo group will exactly be interested in the RB options next to the available cheap sea transport and the existing slower and cheaper railway?

When considering the reliability of the reports it should be once more noted that according to Flyvbjerg (2007: 586), the specialized private consultancy companies are typically engaged in helping to develop project proposals. In general, the interviewees found that consultants showed high professional standard and integrity, but consultants appeared to focus on justifying projects rather than critically scrutinizing them. Next to the overestimation of revenues, there is also a need to accept that average cost overrun for railway projects are 44.7\% (Flyvbjerg 2007: 579)

In the case of RB, none of the assessors have seen the project as fully able to survive under market conditions or attracting private investors. None of the assessors have also admitted that the project can be unprofitable in any of its stages even if one includes the internalisation effect. The AECOM assessment is closest to the second option, stressing that the project is sustainable when the maintenance costs are included but the initial investment is excluded from the service prices. Thus, if the national governments together with the EU will set up the infrastructure, it is expected to be able to last independently. The Ernst \& Young analysis is closest to the third option, admitting that the project is unable to generate sufficient business income to cover its maintenance costs even when

$4 \quad$ LOT is the Polish National Airline company. 
the initial investment is made. Hence, lifetime subsidies are needed. At the same time, the societies should go for the project as the non-internalizable benefits, environmental effects and social benefits are higher than the subsidies required. Several independent experts, like Neivelt and Tammistu agree that the project is not able to generate sufficient cash-flow for covering even the maintenance costs, but are additionally sceptical about the social and environmental benefits.

\section{2. $R B$ as a special device for helping out the EU periphery}

For the less well-off member states and in particular for the peripheral Central and East European (CEE) countries, the fiscal transfers from the Brussels budget as well as the special investments are of utmost importance. Though the much heralded convergence was supposed to bring almost automatically the poorer member states out of their economic backwardness, the annual budgetary transfers and the concrete EU investments have been seen as the more tangible vehicles relied upon while paving the way out of the peripheral status. Yet, the success of these investments is not guaranteed. Thus, the topic chosen is very important and interesting for all 'new member' states of the EU: whether the big investments supported by the EU funds are really and always useful for these countries.

Nevertheless, there are several problematic aspects to be taken into account. Starting with the historical and geographical perspectives, finding support for the RB-type projects is challenging. First, since the introduction of railway, none of the powers ruling the Baltic States has seen any need for a massive Trans-Baltic railway either for economic or security reasons. Second, the geographical argument has generally played a negative role as long as business-oriented cargo railways in parallel to the sea-line are rare to find, for competition with ferries takes away the profitability.

At the same time, the railway network in the Baltics has mostly been serving freight transport, especially of Russian origin. And, recently there has also been a noticeable rise in the passenger transport services. In this context, better railway connections and services between the Baltic States, and indeed with Eastern and Central Europe do not seem an altogether illogical development. Furthermore, the project fits nicely into the current European integration model, which has stability and security as its primary aims. It would bring better connectivity and could thereby enhance economic growth.

All this does not mean that the project needs to be market efficient, or even bring the operators profit and its benefits can be indirect. Indeed, based on the above analysis, it is obvious that the value of RB lies in larger socio-economic benefits and other gains to the society (including the emotional yet vital argument 
of "belonging to Europe"). However, due to the very long payback periods of infrastructure, the delay in construction of the Helsinki-Tallinn rail tunnel, political and economic instability related to Russia, and uncertainty related to potential trade volumes, the RB itself is most likely going to run under deficit at least for the next 20-30 years after the projects will be completed in 2025 .

The problematic aspects are still considerable. RB is expected to boost the cargo volumes in terms of local production and transit as well as the passenger numbers. Still, the Baltic economies are growingly services-oriented, transit from Russia is showing at historically low levels since regaining the independence, and even local civil servants are expected not to use RB for their visits to Berlin, Paris and Brussels. If these factors will not contribute to the viability of the project, what could make RB to meet the claims that have been made for it and that saw it as a central variable, making the Baltic foreign trade and transit to grow and boosting also passenger numbers? To be a success, RB would evidently need to be further connected: the idea of a possible tunnel between Tallinn and Helsinki has also been one of the arguments to support the railway.

Putting forward a negative definition first, the basic logic of the centrally injected investments into regions presumes that neither the market profitability nor the regional capabilities are sufficient to make the investment happen. On the positive side, the precondition is that the indirect benefits from the project are nevertheless guaranteed. However, one cannot turn a blind eye to the fact that $\mathrm{RB}$ was presented first as an economically viable project on its own, i.e. viable on a commercial basis. As it turned out by the findings of the second assessment, this rationale was grossly misleading. This is a problem not only content-wise but also in terms of public relations. Is the management of the RB project reliable as such? Also, retrospectively it appears that the management of the project has not been fully aware of the need to include the difference between straightforward commercial and non-internalisable economic benefits (presented in the Ernst \& Young study but significantly absent in the AECOM study) into the analysis.

There are also further circumstances to be paid attention: if the internalization effect and Europeanization are part of the long term profitability calculation, the owner and operator(s) of the railway should also start to prepare to meet the EU competition policy rules for state aid having effect on market competition (as it is expected that many bus and some plane travellers will choose RB). Thus, there may be a further possible trap awaiting. If RB is able to attract travellers with the help of the state aid it will be illegal, and if they will not be able to attract travellers or freight, then the project is unable to meet its initial aim. The worst-case scenario would be that first the initial construction costs for member states will grow near or more than $100 \%$ compared to the available evaluations, and after the 
completion the operational costs will also be higher than expected and will still be growing during the life cycle. As the subsidies grow, the project will inevitably lose its prestige and the national governments might attempt to sell it with a fraction of the actual costs. This last option, even if following a popular model, might turn out as the most costly one, for besides all the above-mentioned costs, the state subsidies will have to cover the profits of the new owner.

\subsection{Meeting the White Elephant criteria}

Since the start of the project, RB has been introduced as a symbol of the European integration, a good cooperation initiative with the local governments and a sign that Europe needs and addresses the Baltic needs. It has supposedly also been introduced as a symbol of progress and a proof that the EU peripheral areas can also enjoy modern technology and infrastructure, even when the planned technology is, in general, from $20^{\text {th }}$ century and the capacity does not exactly meet the local needs.

In the 2000s, after the transit volumes started to increase in the Baltic countries, the rather emotional argument of "belonging to Europe" was supplemented by a practical need to develop regional transportation options and improve the quality of services. More specifically, in the second half of the 1990s, in the light of the EU membership perspective of Estonia, Latvia and Lithuania, and also as a result of a favourable geopolitical location of the Baltic countries, trade and traffic between these countries and the Western Europe started to increase significantly. In the 1990s, Lennart Meri, the former President of Estonia, expressed a wish to 'take a train from Tallinn to Germany and to be in Berlin in seven hours', like it was in his childhood (Interview with... 1999: 1). The last evaluation of Ernst \& Young, however, states clearly that the main focus is on the local travels between Tallinn-Riga-Vilnius, and not the symbolic link to Berlin and Paris.

The "build and they will come" syndrome is evident in both of the assessments: the needed transit and cargo volumes also do not yet exist. Even when the existing Baltic railways are suffering from poor volumes, it is expected that the new clients will appear despite the prices being higher and the economies being growingly service-oriented rather than industry-oriented. The existing railway anyway needs maintenance costs and will take away some (not speed dependent) trade flows which will make the profitability complicated. Actually, the trade flow needs to grow to get even the existing railway to a balancing point. Compared to the present, RB will create a situation where the maintenance costs grow remarkably while the trade flows will still depend on the market needs and the industrial capabilities. Based on the assessments, so far the main benefit for the Baltic States will be the RB infrastructure itself. 
Security arguments have also been included in the discussion. To quote the former Prime Minister of Estonia, Taavi Rõivas, "A modern high-speed rail is important to Estonia, Latvia, Lithuania, as well as for the unity of Europe, integrating our region more closely with our allies and partners" (The Baltic Course 2015: 1). But the security aspect may well be of a symbolic rather than practical value as far as the functionality of railways depends on the rail tracks, a hardly invulnerable target in military terms.

The timeframes are both compressed and unclear, while the Baltic states have already been in a deep trouble with the Via Baltica motorway construction since 1991. It is expected that RB will be operational by 2025 , with no actual construction started in 2017.

As it seems, none of the assessors have been focusing on specifying the level of certainty and trustworthiness of the project plans. For taxpayers, both the general volumes and shares of the national governments have been steadily growing. The assessors, however, have only brought out the cost for an average operational year (2035), thus not touching the question of the potentially growing costs during the years of use.

$\mathrm{RB}$ is developed by the European regional development funds, no private investors or local governments have seen this project as economically attractive. However, the measurable financial gains will end up with large non-local companies, building and supplying the relevant equipment for RB, while the local companies are only expected to assist the project and are planned to gain social and environmental benefits. At the same time, the local member state governments are supposed to cover roughly $30 \%$ of the initial costs. Should the White Elelphant scenario become real, it would make them effective net-payers. The independent critical assessors have also emphasized that the benefits will mainly be related to the construction stage of RB.

As the existing project assessments analysed in the current study are initiated by stakeholders interested in the positive feedback, the assessments are therefore seen as overly optimistic or even naive by independent evaluators (Neivelt 2017). While certain optimistic aspects, like social and environmental gains are presented, it remains unclear who will cover the life-long gap between the RB income and the actual maintenance and management costs and how. Instead of opting for a reliable analysis and adjusting the project to the needs of real life, the institutions have opted for the plan they have initially chosen. This clearly refers to emotional arguments, institutional motives and path dependence that could, in principle, lead to an irrational allocation of resources and to a "lock-in"-situation. In case rational and measurable arguments run out, the symbolic ones tend to take over: 'It is our only stable road connection to Europe' and 'the current offer is unique'. 
On a more specific scale, similar railways running in Sweden and Portugal have not been used for efficiency analysis or for avoidance of too optimistic calculations. The Baltic States themselves have a rather calming experience with regard to high internalization effect in parallel with low direct income with national airlines. For example, Air Lithuanica and Estonian Air have gone bankrupt, and airBaltic functioning only with massive injections of the state aid.

\section{CONCLUSIONS}

The topic of this article is vital for all new member countries of the EU: whether the big investments supported by the EU funds are really and always useful for these countries. The issue is much more than an economy based cost-benefit or macroeconomic question: it brings also geopolitical, centrum-periphery, sociopsychology or institutional decision-making problems into the subject. The current study outlined first a survey on selected possible approaches to the issue, and in the second part it established whether the Rail Baltica project fits with the 'White Elephant' criteria.

First, it is remarkable that none of the available lessons from previous similar projects related to over-optimistic expectations, growing costs, possible management mistakes, dominance of political goals over economic ones have been included in the assessments.

In terms of the White Elephant syndrome, most of the criteria listed by the theoretical sources were met, some are yet to be assessed when the project moves forward to the construction stage. It is already evident though that the politicians of the Baltic States have anchored to the RB project and promote it as a national dream.

There are two facets to this problem. If the project is not only commercially over-scaled but also brings costs to the member state that surpass even the widest possible returns (i.e. the non-internalizable economic benefits), one can talk about a straightforward White Elephant. For a peripheral area, these kinds of infrastructure investments should essentially be able to pull the member states and regions out from a generally unfavourable situation. Curiously, the EU should tend to leave these costs to the member states themselves to bear from their public budgets, as the 'investment' is not so much adding to the available pool of resources, but rather rechanneling peripheral resources to cover permanent losses.

Past examples show that on average similar projects generate $44 \%$ higher costs than expected while revenues are overestimated. The main risk of the RB project lies in it being over-dimensioned and lacking a possibility of down-scale. In its 
current shape, according to the latest assessment, the RB project will not be financially viable (both in terms of an immediate commercial basis and on a wider societal scale). At the same time, the public communication of the project has focused on convincing the general public that the project is still economically viable in market terms, although it is becoming increasingly clear that it will not be so.

It is also hardly understandable how a railway parallel to the sea and starting from a sea port could have a high transit value. Indeed, the foremost question touches the availability of sufficient cargo and passenger volumes to make the RB project work. To be profitable, RB would evidently need to be further connected: the idea of a possible tunnel between Tallinn and Helsinki has thus been one of the arguments to support the railway.

In case of being over-dimensioned, RB will not be economically viable (including enhanced security) and needs constant subsidies to cover the gap between the direct and indirect incomes and the maintenance cost. From a practical perspective, the question emerges of who would have to bear the costs, the member states or the EU? This is a crucial moment for an EU member state: will the European subsidies cover the possible loss?

\section{REFERENCES}

Ackermann, R. (2001): Pfadabhängigkeit, Institutionen und Regelreform. Die Einheit der Desellschaftswissenschaften. Studien in den Grenzbereichen der Wirtschafts- und Sozialwissenschaften. Tübingen: Mohr Siebeck.

Chancellery of the President of the Estonian Republic (1999): Interview with the President Lennart Meri (in Estonian), Postimees, 21 September 1999. https://vp1992-2001.president.ee/est/k6ned/ Intervjuu.asp? ID $=4532$

Crocioni, P. - Newton, C. (2007): State Aid to European Airlines, a Critical Analysis of the Framework and Its Application. In: Lee, D. (ed.): Advances in Airline Economics, the Economics of Airline Institutions, Operations and Marketing, 2, pp.: 147-170, Elsevier B.V.

David, P. A. (2000): Path Dependence, Its Critics and the Quest for "Historical Economics". All Souls College, Oxford \& Stanford University. http://www-siepr.stanford.edu/workp/ swp00011.pdf

Döring, H. - Rose, J. (2002): Pfadabhängigkeit und die Machbarkeit von holistischen Reformen. Humboldt-Universität zu Berlin.http://www.hwiesenthal.de/projekte/polrat/doering_rose.pdf

European Commission (2011a): Regulation of the European Parliament and of the Council on Union, Guidelines for the Development of the Trans-European Transport Network. http://eurlex.europa.eu/legal-content/EN/TXT/PDF/?uri=CELEX:52011PC0650\&from=EN

European Commission (2011b): Connecting Europe: The New EU Core Transport Network. Memo 11/706. http://europa.eu/rapid/press-release_MEMO-11-706_en.htm

European Commission (2013): Trans-European Transport Network. http://ec.europa.eu/transport/ infrastructure/tentec/tentec-portal/site/maps_upload/SchematicA0_EUcorridor_map.pdf 
European Commission (2014): Estonia: Core Network Corridor. https://ec.europa.eu/transport/ sites/transport/files/tent_et.pdf

European Commission (2016): Baltic Adriatic. Second Work Plan of the European Coordinator. December 2016. http://ec.europa.eu/transport/sites/transport/files/tent-coordinators-2nd-workplan-bac.pdf

European Commission (2017a): Scandinavian-Mediterranean Core Network Corridor. https:// ec.europa.eu/transport/themes/infrastructure/ten-t-guidelines/corridors/scan-med en

European Commission (2017b): Infrastructure - TEN-T - Connecting Europe. EU Funding for TEN-T. https://ec.europa.eu/transport/themes/infrastructure/ten-t-guidelines/project-funding_en

European Parliament (2015): The Results and Efficiency of Railway Infrastructure Financing within the EU. http://www.europarl.europa.eu/RegData/etudes/STUD/2015/552308/IPOL STU(2015)552308_EN.pdf

Flyvbjerg, B. (2007): Policy and Planning for Large-Infrastructure Projects: Problems, Causes, Cures. Environment and Planning B: Planning and Design, 34(4): 578-597.

Koppel, O. (2017): Some Side Notes about Rail Baltic. Baltic Rim Economies, 1 February 2017, p. 30. http://www.utu.fi/en/units/tse/units/PEI/BRE/Documents/BRE_1_2017.pdf

Lend, E. (2016): Professor of Logistics: In Assessing the Case of Rail Baltica, we should Follow the Logic of Logistics Not from Fairy Tale Story of Pinocchio. Postimees, 30 September 2016. http://majandus24.postimees.ee/3856187/logistikaprofessor-rail-balticu-puhul-tuleks-lahtudamitte-buratinost-vaid-logistikast?.ga $=1.43072803 .703699133 .1475121518$

Mangan, J. A. (2008): Prologue: Guarantees of Global Goodwill: Post-Olympic Legacies - Too Many Limping White Elephants? The International Journal of the History of Sport, 25(14): $1869-1883$.

Massey, D. B. (1979): In What Sense a Regional Problem? Regional Studies, 13: 233-243.

Ministry of Internal Affairs (2013): National Spatial Plan Estonia 2030+. https://eesti2030.files. wordpress.com/2014/02/estonia-2030.pdf

Neivelt, I. (2014): Indrek Neivelt about Rail Baltica: The Travel with Train to Berlin would be Slow and Expensive (in Estonian): 25 January 2014. http://arileht.delfi.ee/news/uudised/indrekneivelt-rail-balticust-soit-rongiga-berliini-on-kulukas-ja-aeglane $2 \mathrm{id}=67676957$

Nijkamp, P. (1986): Infrastructure and Regional Development: A Multidimensional Policy Analysis. Empirical Economics, 11(1): 1-21.

Papanikolaou, P. (2013): Athens 2004. Ten Years Later the Olympic Infrastructure, the Cultural Olympiad and the 'White Elephant' Syndrome. Journal of Power, Politics and Governance, 1(1): 1-9.

Prasser, S. (2007): Overcoming the 'White Elephant' Syndrome in Big and Iconic Projects in the Public and Private Sectors. In: Improving Implementation: Organisational Change and Project Management. Australian National University e-Press, pp. 47-67. http://epress.anu.edu.au/anzsog/imp/pdf/ch05.pdf

Rail Baltica Final Report (2011): AECOM, May 2011. http://www.tja.ee/public/Raudtee/Rail Baltica_Final_Report_Volume_I_31_05_11_FINAL_v2.pdf

Rail Baltica Global Project Cost-Benefit Analysis. Executive summary (2017): http://railbaltica. org/wp-content/uploads/2017/04/RB-CBA-Final-Executive-summary.pdf

Rail Baltic (2015): The Rail Baltic Project. Official website of the Rail Baltic. Published on 1 July 2015. http://railbaltic.info/en/

Rail Baltic (2016): Road of the Future. http://www.railbaltica.org/en/about-the-project

Stephan, A. (2001): Regional Infrastructure Policy and Its Impact on Productivity: A Comparison of Germany and France. CIG Working Papers, FS IV 01-02. 
Structural and Cohesion Policies (2014): Update on Investments in Large TEN-T Projects. Part II - Case Studies. European Parliament, Directorate-General for Internal Policies, Policy Department B. http://netlipse.eu/media/84090/update-on-investments.pdf.

The Baltic Council of Ministers (2005): Report on the Cooperation between the Baltic States in the Transport Sector. September 2005, 15 p.

The Baltic Course (2015): Estonian Government Supported RB Funding Application. 6 February 2015. http://www.baltic-course.com/eng/transport/?doc=102102

The Baltic Course (2016): Baltic States have Agreed on VAT Revenue Distribution by RB Construction. 22 June 2016. http://www.baltic-course.com/eng/transport/?doc=122449

The Rail Baltic Project (2015): Official Website of the Rail Baltic. 1 July 2015. http://railbaltic. info/en/

Thorsen, D. E. (2009): The Neoliberal Challenge. What is Neoliberalism? University of Oslo, Working Paper, October 2009. http://folk.uio.no/daget/neoliberalism2.pdf

Veebel, V. - Ploom, I. - Kulu, L. (2015): Shortcomings of the EU State Aid Model from Peripheral Perspective: The Case of Estonian Air. Baltic Journal of Economics, 15(1): 50-64.

Vining, A. R. - Weimer, D. L. (1990): Government Supply and Government Production Failure: A Framework Based on Contestability. Journal of Public Policy, 10 (1): 1-22.

Wetzel, A. (2005): Das Konzept der Pfadabhängigkeit und seine Anwendungsmöglichkeiten in der Transformationsforschung. Freie Universität Berlin, Arbeitspapier, No. 52.

Winston, C. (2006): Government Failure versus Market Failure. AEI-Brookings Joint Center for Regulatory Studies. https://www.brookings.edu/wp-content/uploads/2016/06/20061003.pd 